\title{
The non-marine Ostracoda of Lapland: changes over the past century
}

\author{
Anna IGLIKOWSKA, ${ }^{1,2^{*}}$ Tadeusz NAMIOTKO ${ }^{2}$ \\ ${ }^{1}$ Institute of Oceanology, Polish Academy of Sciences, Department of Marine Ecology, Powstańców Warszawy 55, 81-712 Sopot, \\ Poland; ${ }^{2}$ University of Gdańsk, Department of Genetics, Laboratory of Limnozoology, Kładki 24, 80-822 Gdańsk, Poland. \\ *Corresponding author: iglikowska@iopan.gda.pl
}

\begin{abstract}
Novel faunistic data are presented from the poorly explored area of northern Lapland and comparisons are made between the present day ostracod diversity and historical records from a century ago. Twenty sites were sampled across Norwegian, Swedish and Finnish Lapland: eight to the west of the Scandinavian Mountain range, where the climate is milder under the influence of the Gulfstream, and 12 sites in the slope area east of these mountains, where the impact of the continental climate is stronger. The sample sites were mainly peat bogs fed by springs (the dominant habitat type in the study area), but also included helocrene springs, ditches, ponds and the littoral zone of lakes.

In total 4376 individuals belonging to 16 species were collected. The most widespread and abundant species were Cyclocypris ovum, Candona candida and Pseudocandona rostrata, whereas Cyclocypris serena, Cryptocandona vavrai and Eucypris pigra were least abundant. The diversity of the ostracod assemblages to the west and to the east of the Scandinavian Mountains was significantly different, as measured by the Shannon diversity index. Mean values were 0.36 (western slopes) and 0.84 (eastern slopes).

Three assemblage types were distinguished using UPGMA cluster analysis, with $\mathrm{C}$. ovum, $\mathrm{C}$. candida and $\mathrm{P}$. rostrata as the three characteristic species. However, no statistically significant differences were revealed between the ostracod site assemblages when grouped geographically into west and east of the Scandinavian Mountains. Our results did not show any significant correlation between the Bray-Curtis similarity of the ostracod assemblages and the geographical separation between sites.

The most marked difference in ostracod diversity between the present data and the records from the beginning of the $20^{\text {th }}$ century seems to be a retreat of some Arctic species from the Lapland area and a shift of a few eurytopic species further to the north of Lapland. Possible factors influencing this shift are discussed.
\end{abstract}

Key words: subarctic Ostracoda, peat bogs, Norway, Sweden, Finland, Arctic warming.

Received: November 2011. Accepted: February 2012.

\section{INTRODUCTION}

Accumulated knowledge on the occurrence and diversity of freshwater ostracods in northern Europe is fragmentary. Records of ostracods from Lapland north of the Arctic Circle were first published at the turn of the $19^{\text {th }}$ Century into the first decades of the $20^{\text {th }}$ Century. Ekman $(1908,1914)$ and Alm $(1914 b, c, 1915)$ reported a total of 17 species from the Swedish Lapland area (primarily in the Sarek mountains and the vicinity of Lake Torneträsk), but Sars $(1890,1925)$ and Alm (1914a) found only five species in the Norwegian part of Lapland (Finnmark and the west coast of Nordland). Finnish Lapland, apart from a note on one species in Alm's (1915) monograph, has been a terra incognita until recent contributions by Tolonen (1997) and Iglikowska and Namiotko (2010, in press) who built an inventory of 17 species from the area.

Lentic systems north of the Arctic Circle comprise numerous lakes, ponds and wetland systems (ACIA, 2005). To obtain a more comprehensive assessment of freshwater ostracod diversity in Lapland, existing data on the deep lake ostracod fauna (Iglikowska and Namiotko, 2010) and on the fauna of shallow lakes, peat bogs and temporary pools (Iglikowska and Namiotko, in press) are supplemented here with records from water bodies fed by spring water, including records from Swedish Lapland where no studies have been carried out since Ekman (1908).

Mean annual air temperatures in Finnish Lapland rose 1 to $2^{\circ} \mathrm{C}$ following the Little Ice Age ( 1840 until the mid20th century) (ACIA, 2005). Changes in water temperature, mixing regimes and stratification of Lapponian lakes seem to be associated with climate change, and, on broader scale, probably influence species composition (e.g. diatoms; Agbeti et al., 1997; Sorvari and Korhola, 1998). Adaptations of arctic and boreal species to their current environments may limit their responses to climate warming and other ecosystem changes. These adaptations have evolved in response to harsh climate conditions so arctic species may be more vulnerable to biological invasion at their southern ranges, while species at their northern range limit are particularly susceptible to warming (ACIA, 2005).

In the context of rapid changes in freshwater environments of the northern area, basic faunistic research is urgent (Heino et al., 2009). This study helps to fill a gap in 
our knowledge by creating an up to date faunal inventory of the ostracods of a poorly explored area of northern Lapland which will allow us to detect changes in diversity patterns and species composition over the past century, as well as serve as a baseline against which future changes can be assessed.

\section{METHODS}

In this study the term Lapland is applied to the regions of Norwegian, Swedish and Finnish Lapland (Fig. 1), but all samples were taken only in the region to the north of the Arctic Circle $\left(66^{\circ} 33^{\prime} \mathrm{N}\right)$. The sample area lies across two freshwater ecoregions: the Catchment Area of the Norwegian Sea and the Catchment Area of the Northern Baltic Sea (Nos 405 and 406 in the system of Abell et al., 2008). Geologically, the bedrock of northern Norway is part of the Caledonides consisting mainly of pre-Cambrian metamorphic and igneous rocks (Szeroczyńska et al., 2006), however the Finnish part contains mainly acidic granites, schists, granodiorites and gneisses (Pulkkinen and Rissanen, 1997). The low pH of the rock, low air temperature and high humidity impede decomposition and mineralization of organic matter promoting the formation of acidic soil (Stebel et al., 2007).

The climatic conditions of northern Fennoscandia are impacted by at least two different drivers: from the west is the strong influence of air masses warmed by the Gulfstream (especially in winter), and from the east is the cooling effect of the Arctic, continental air from Eurasia. The Scandinavian Mountains (or Scandes range) play an important passive role in shaping the climate of Fennoscandia, limiting the effect of the Atlantic air masses to the western slopes (Martyn, 1995; ACIA, 2005; Tikkanen, 2005). The average air temperature in January on the Atlantic coast of Norway (about $0^{\circ} \mathrm{C}$ ) is unusually high for this latitude and the annual range in air temperature is

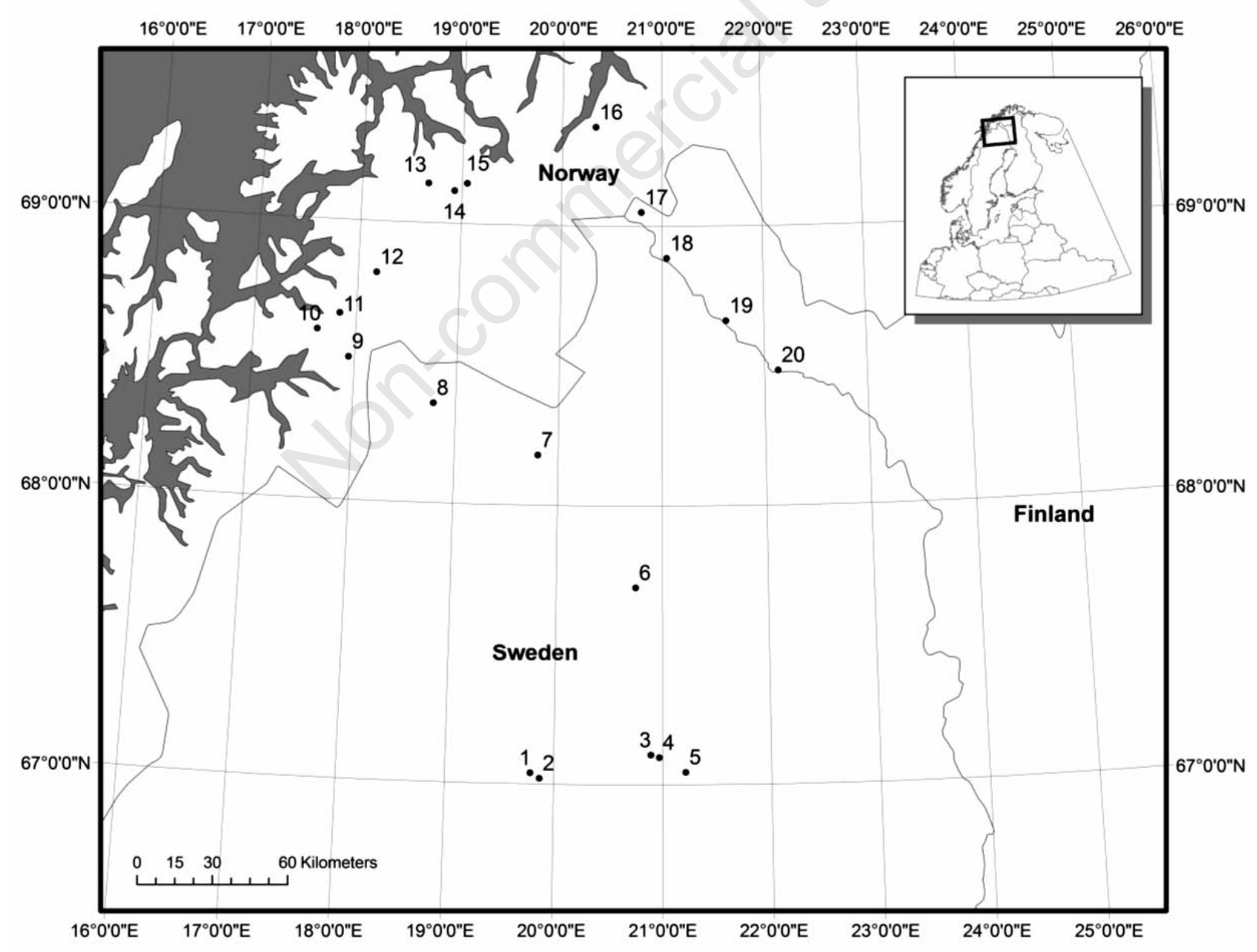

Fig. 1. Location of the studied sampling sites in Lapland. 
about $10^{\circ} \mathrm{C}$. In addition, the annual precipitation is about $4000 \mathrm{~mm}$ (near Bodø) and snow cover remains four months (Selin and Hakkari, 1982; Tikkanen, 2005). In contrast, east of the Scandinavian Mountains has an annual temperature range of up to $29^{\circ} \mathrm{C}$ (in the Finnmark region), precipitation does not exceed $400 \mathrm{~mm}$, and snow cover remains for approximately seven months (Selin and Hakkari, 1982; Tikkanen, 2005; Stebel et al., 2007). The subarctic vegetation zone is characterized by pine and subalpine mountain birch forests, and also includes the northern sloping fens and the Palsa mire complex (Luoto and Seppälä, 2000; Paiunen, 2005).

In this study 20 sites were sampled (Tab. 1): eight to the west of the Scandinavian Mountains and 12 sites to the east (Fig. 1, Tab. 1). Eight of the study sites were located in Swedish Lapland in the provinces of Torne Lappmark (Tolp) and Lule Lappmark (Lulp), eight in the west coast area of Norway, in the region of Troms Indre (TRI), and the remaining four were located in Finnish Lapland, in the province of Lapponia Enontekiensis (Le) (regions, names and abbreviations of the biogeographical provinces follow the format of the Fauna Entomologica Scandinavica series). Sample sites were mainly peat bogs fed by springs (the dominant type of habitat in the study area), but also included helocrene springs, ditches, pond and the littoral zone of lakes.

Sampling was carried out in July 2003 and August 2004. Ostracods were collected qualitatively using a 120 $\mu \mathrm{m}$ mesh hand net and then kept in plastic containers in $75 \%$ ethanol. In the laboratory, samples were filtered under tap water through $120 \mu \mathrm{m}$ sieve and preserved in $96 \%$ ethanol. Individuals were sorted and identified under stereo-microscope and standard light microscope using keys by Sywula (1974) and Meisch (2000). Taxonomic identifications were based on valve morphology and soft body parts.

Species diversity of the ostracod site assemblages were estimated using both the Shannon-Wiener index (H') and the average taxonomic diversity $\left(\right.$ Delta $\left.^{+}\right)$index, which is a mean taxonomic distance between every pair of individuals in a sample (Clarke and Warwick, 1998). The average taxonomic diversity index is used to distinguish site assemblages with the same number of species but with different taxonomic affinity (for details of this method see Clarke and Warwick, 2001 and Clarke and Gorley, 2006).

A hierarchical cluster analysis of Unweighted Pair Group Mean Averages (UPGMA) based on Bray-Curtis similarity coefficient and relative abundances (percentages), was used to identify ostracod assemblage types. The statistical significance of the UPGMA grouping was confirmed by the permutation test (with 999 simulations) of similarity profile (SIMPROF). Additionally, after the cluster analysis, the method of similarity percentages (SIM-

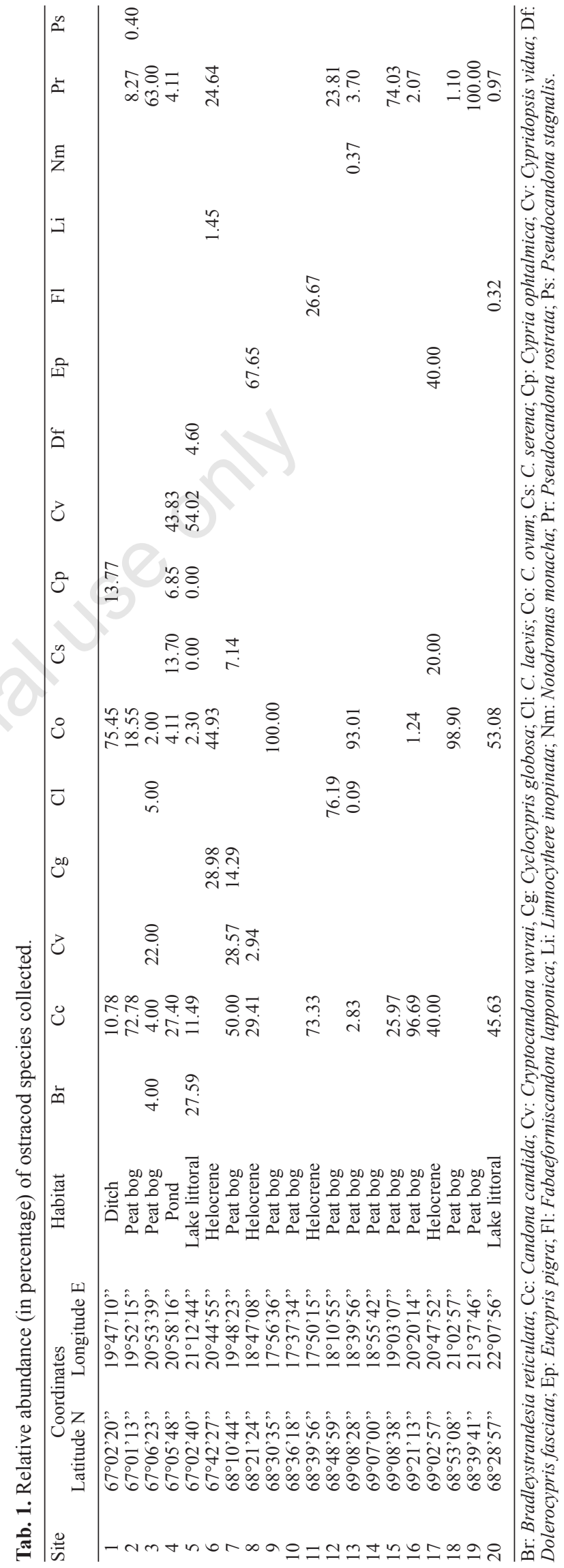


PER) was employed, to assess which species are principally responsible for the separation of the different assemblages (Clarke and Warwick, 2001; Clarke and Gorley, 2006).

A non-parametric permutation test ANOSIM (Analysis of Similarities) (Clarke and Warwick, 2001) was used to test for differences between the structure of the site assemblages grouped by location (either on the eastern or western side of the Scandinavian Mountains). Finally, in order to test whether faunistic similarity was correlated with geographical distance, the RELATE test was employed.

All analyses were conducted using PRIMER ver. 6.1.10. software package (Clarke and Gorley, 2006).

\section{RESULTS}

During the survey 4376 individuals were found. Only two of 20 samples (sites 10 and 14) did not contain any ostracods. Ostracod abundance from the other sites differed in total numbers, with a mean of $243 \pm 505.1$ individuals per sample ( \pm standard deviation). Sixteen species were found (Tabs 1 and 2) but the overall species richness (number of species) at each sampling site was generally low, varying between 1 (sites 9 and 19) and 6 (sites 3 and 4 ), with an average of $3.3 \pm 1.5$ species per site. Across all sites the most widespread and abundant species were $C y$ clocypris ovum ( $65 \%$ of total abundance, collected from $61 \%$ of sites), Candona candida ( $22 \%, 72 \%$, respectively) and Pseudocandona rostrata (7\%, 61\%, respectively). Furthermore, $C$. candida was the dominant species noted in $50 \%$ of all samples, with an average contribution of $51 \%$. Rare species included Cyclocypris serena as well as crenophilic Cryptocandona vavrai and Eucypris pigra.

The mean value of the Shannon-Wiener index $\mathrm{H}^{\prime}$ for the 18 sites where ostracods were found was 0.678 , whereas the mean value for average taxonomic diversity (Delta+) equalled 51.15. The highest H' value was observed at station $4\left(\mathrm{H}^{\prime}=1.435\right)$, but the value of Delta + was relatively low (Delta $+=60$ ). The reduced Delta + value reflects the contribution of a single taxon, the family Candonidae, to which five of the six species from this site belonged (Tab. 2). The difference between the average values of the H' species diversity for the sites located on the west slopes of the Scandinavian Mountains $(0.364 \pm 0.244)$ and for those from the east $(0.842 \pm 0.439)$ was statistically significant (Mann-Whitney test, $\mathrm{U}=10.5, \mathrm{P}=0.019$ ).

Three assemblage types were distinguished by UPGMA cluster analysis (Fig. 2) and validated by the SIMPROF significance test $(\pi=2.92-5.89, \mathrm{P}=0.05)$. The first cluster consisted of samples from sites 3, 12, 15 and 19 , and the average Bray-Curtis faunal similarity between the site assemblages was $46.7 \%$. P. rostrata was the characteristic species of this assemblage type based on SIMPER analysis. The second, more coherent (with an average mutual similarity between site assemblages of $74.3 \%$ ) assemblage type comprised samples from five sites $(1,9,13,18$ and 20) and was characterized by the clear dominance of C. ovum. Finally, the third assemblage type was composed of eight samples (sites 2, 4, 5, 7, 8, 11, 16 and 17), with Candona candida as its indicator species. The average mutual similarity between the site assemblages of this cluster was $37.7 \%$.

No significant statistical difference was found between the structure (species composition and their relative percentage abundances) of the site assemblages on the eastern and western sides of the mountains (employing the ANOSIM test, $\mathrm{R}=0.043, \mathrm{P}=0.349$ ). Furthermore, our results did not show a statistically significant correlation between the values of the Bray-Curtis similarity coefficient and the geographical separation of the sample sites (RELATE test, $\rho=-0.141, \mathrm{P}=0.978$ ).

\section{DISCUSSION}

The 16 species noted in this study constitute $57 \%$ of the total of 28 recent freshwater ostracod species reported previously from the Norwegian, Swedish and Finnish parts of Lapland north of the Arctic Circle. Two species, Notodromas monacha and Limnocythere inopinata, were new to the area, so the present collection brings the total number of recent non-marine ostracod species in Lapland to 30 . The occurrence of $L$. inopinata in Lapland north of the Arctic circle was not unexpected as this species has previously been reported close to the Arctic Circle in Fennoscandia (Tjøtø, Nordland, Norway, latitude ca. 65 50': Sars, 1925), and even further North in the Arctic archipelagoes of Svalbard (Hartmann, 1992) and Novaya Zemlya (Semenova, 2003). N. monacha has also been previously recorded from a locality very close to the Arctic Circle in Fennoscandia (near Ruskola, Norrbotten, Sweden, latitude ca. 662': Alm, 1915), although this species has been considered to be a warm stenothermal form (Meisch, 2000). This new record (site 13) at a latitude of $69^{\circ} 08^{\prime} \mathrm{N}$ in Norway is the northernmost location of this species in Europe. We recorded only $57 \%$ of the 28 previously reported species: the absence of the other $43 \%$ probably primarily reflects the differences in sampling effort. Our samples were taken during two fieldwork seasons, whereas existing data were accumulated from the effort of several researchers over at least three decades.

In the present study the dominant species were either eurybiontic species (Candona candida, Cyclocypris laevis, C. ovum, Cypria ophtalmica, Pseudocandona rostrata and Cypridopsis vidua) or species characteristic for astatic pools and peat bogs (Bradleystrandesia reticulata, Cyclocypris globosa, C. serena, Fabaeformiscandona lapponica and Pseudocandona stagnalis) (Tab. 1).

In the UPGMA cluster analysis (Fig. 2) three ostracod assemblage types were identified, with Candona candida, Cyclocypris ovum and Pseudocandona rostrata as indi- 
The non-marine Ostracoda of Lapland: changes over the past century

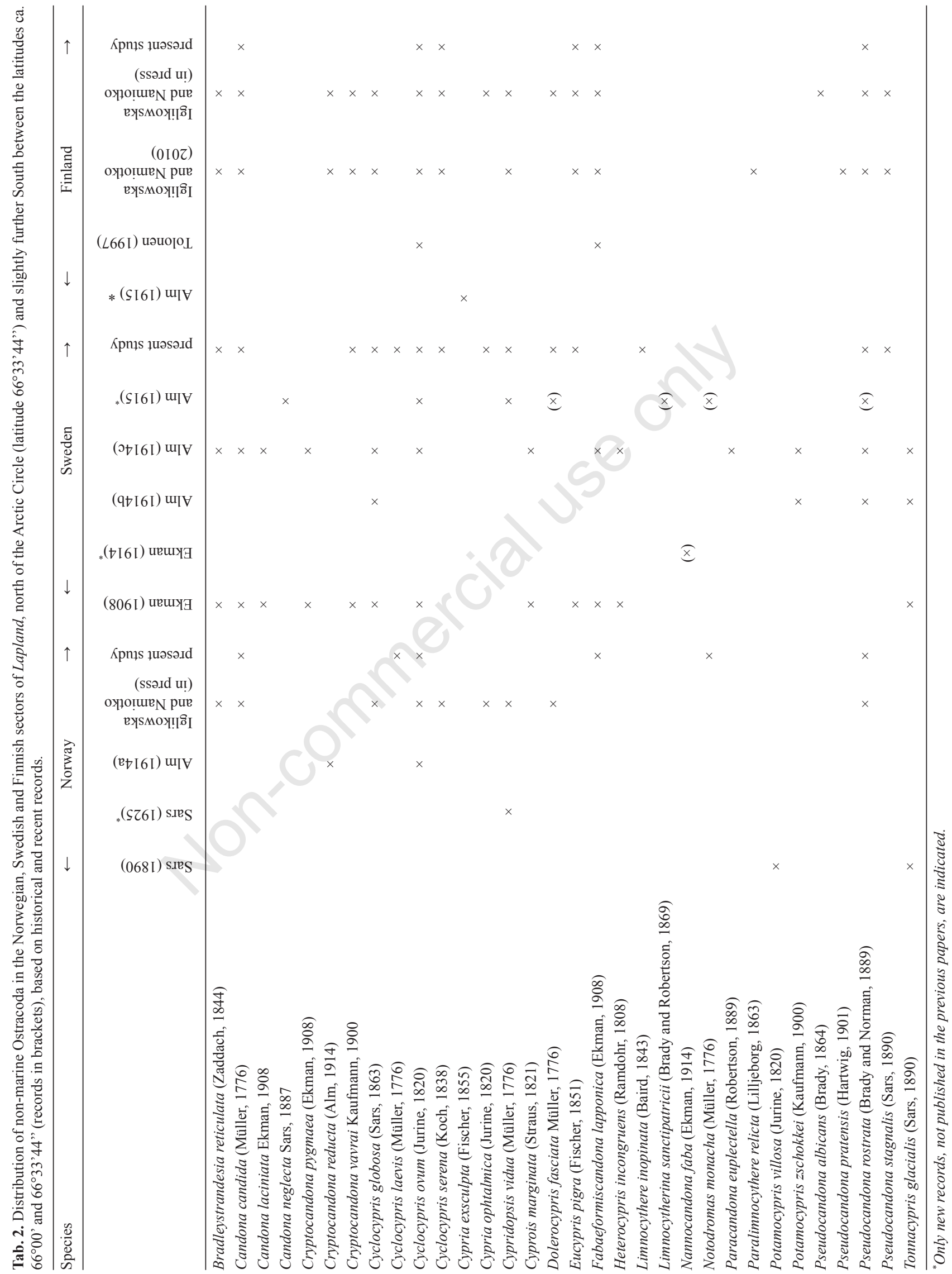


cator species. Although we noted three assemblage types we found that the average mutual Bray-Curtis similarity between the site assemblages was relatively low. Our previous research on the ostracod fauna of Inari Lapland (Iglikowska and Namiotko, 2010) and our comparison with the ostracod fauna of Poland (Iglikowska and Namiotko, in press), revealed that all Lapponian assemblages are drawn from a single coherent assemblage type, regardless of habitat type. Dominance of any one of the three mentioned species may simply reflect factors such as the timing of colonization of the habitat.

Species diversity of the sites located on the western slopes of the Scandinavian Mountains $\left(\mathrm{H}^{\prime}=0.36\right)$ was significantly lower than that of the sites from the eastern side $\left(H^{\prime}=0.84\right)$. The two sites (sites 10 and 14) where no ostracods were found are both situated on the western side. Nevertheless, no significant difference was found between species composition at sites either side of the mountain range (ANOSIM test). One can infer that the influence of the contrasting climatic conditions is not strong enough to shape the diverse assemblages of peat bog ostracods on the western and eastern slopes of the Scandinavian Mountains. The majority of stations comprise reservoirs fed by spring water: such a permanent inflow of ground water probably ensure relatively constant environmental conditions. The Delta + value reflects not only species diversity, but also taxonomic relatedness of the individuals in sample. At station 4, for example, the highest number of species was found (six), but three belonged to one subfamily Cyclocypridinae, and five to one family, the Candonidae. The low value of Delta+ in the sample, conflicts with the high value of $\mathrm{H}^{\prime}$ index, but is a result of the close taxonomic affinity of the species within that sample.

There were no true high latitude or Arctic and/or boreal species recorded, except for Fabaeformiscandona lapponica, which was sampled at two sites, one to the west (site 11) and one (site 20) to the east of the Mountains (Fig. 1, Tab. 1).

Ekman (1908, 1914) and Alm (1914b,c, 1915) reported 17 species of ostracods from Swedish Lapland (Tab. 2). In the present survey 14 species were found in the Swedish area, eight of which were recorded by Ekman (1908, 1914) and Alm (1914b,c, 1915): namely Bradleystrandesia reticulata, Candona candida, Cryptocandona vavrai (as Cryptocandona longipes), Cyclocypris globosa, C. ovum, Cypridopsis vidua, Eucypris pigra and Pseudocandona rostrata. A remarkable difference between the surveys conducted at the beginning of the $20^{\text {th }}$ century and the present survey is the absence of the boreal and Arctic species Candona laciniata, Fabaeformiscandona lapponica and Tonnacypris glacialis, from the current survey. In recent decades the absence of Arctic species generally has been reported in Russian Lapland (Akatova and Järvekülg, 1965; Vekhov, 2001) and Finnish
Lapland (Iglikowska and Namiotko, 2010; 2011).

The ostracod fauna of northern Norway, in the Troms region has not previously been surveyed, but scattered records exist of five species from the adjacent Nordland and Finnmark regions (Sars, 1890, 1925; Alm, 1914a), including the Arctic species Tonnacypris glacialis (Tab. 2). Of these five species only the eurytopic widely tolerant Cyclocypris ovum and Cypridopsis vidua were collected during the current study and our recent contribution (Iglikowska and Namiotko, in press) from the Norwegian part of Lapland.

Tolonen (1997) and Iglikowska and Namiotko (2010; 2011) recorded a total of 17 species from Finnish Lapland, only one of which, F. lapponica, is boreal. There are no historic records from this area available for comparison.

In summary, this study together with that of Iglikowska and Namiotko (2011) has increased the number of species known from the Norwegian part from five to 15, and from the Swedish part from 17 to 23 (Tab. 2). Eighteen species were found in Finnish Lapland. These three sectors of Lapland exhibit fairly similar levels of species richness and faunal similarity between the three is reasonably high, ranging from 63 to $67 \%$ (Sørensen presence/absence similarity coefficient). Out of 30 species known from the whole area of Lapland, 10 species are common to all three areas: Bradleystrandesia reticulata, Candona candida, Cyclocypris globosa, C. ovum, C. serena, Cypria ophtalmica, Cypridopsis vidua, Dolerocypris fasciata, Fabaeformiscandona lapponica and Pseudocandona rostrata (Tab. 2).

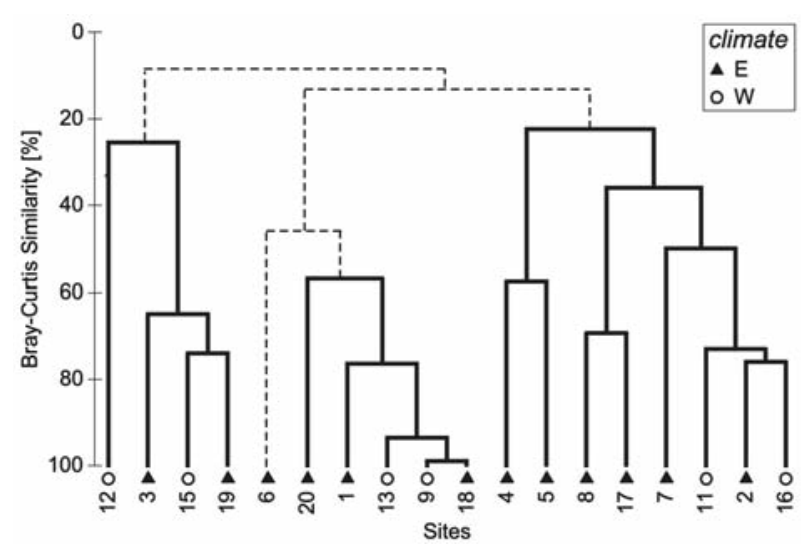

Fig. 2. The UPGMA dendrogram obtained on the basis of relative abundances (percentages) and Bray-Curtis similarity (\%) matrix between ostracod assemblages from the sampling sites in Lapland. Statistically significant separation of the genuine clusters (i.e. main ostracod assemblage types) proven by SIMPROF test are marked by black lines (dashed line of all other branches - no statistical evidence for any sub-separation was found). E (W): sites located on the east (west) side of the range of Scandinavian Mountains. 
Iglikowska and Namiotko (2010) found no significant correlation between habitat type and ostracod species composition in Lapland. In the current study the most noticeable change from the beginning of the $20^{\text {th }}$ century seems to be a retreat of the Arctic species C. laciniata and T. glacialis in Lapland. However, they can still be found in areas to the North of Lapland, such as Franz Josef Land, Svalbard, Novaya Zemlya and the Vaigach Island (Hartmann, 1992; Sywula et al., 1994; Vekhov, 2000a,b, 2001; Semenova, 2003; Wojtasik, 2008). Freshwater arctic ecosystems are particularly sensitive to climate change because they are heavily influenced by interactions between temperature, permafrost and precipitation. Also species limited by temperature and nutrient availability are likely to respond to temperature change (ACIA, 2005). A biogeographical shift of cold-water species in response to climatic warming has been reported for the Northeastern Atlantic marine plankton (Beaugrand et al., 2002) and for freshwater species (Smol et al., 2005) over the past six decades. Even slight warming can result in declining ice cover and a longer growing season for phytoplankton (Korhola et al., 2002). Consequent higher primary production and taxonomic shifts within the algal and invertebrate communities influence the higher trophic levels, and finally result in ecological reorganization, with a northward extension of warm-water species (Beaugrand et al., 2002; ACIA, 2005; Smol et al., 2005).

According to data from the European Climate Assessment and Dataset (ECA\&D) the annual mean of average daily temperature in Lapland has increased $0.5^{\circ} \mathrm{C}$ per decade from 1951 to 2010 . Arctic freshwater systems contain a diversity of organisms that are adapted to the severe environmental conditions to which they are exposed (e.g. strategies incorporating resting stages, diapause, unique physiological mechanisms to store energy and nutrients, an ability to grow and reproduce quickly during short growing seasons, etc.) (ACIA, 2005). As a result of climate warming, some species will probably reach their temperature threshold for survival. Changes in diatom and cladoceran composition since 1850 have been recorded in the lakes of Finnish Lapland and it has been postulated that recent temperature increases have driven the observed ecological changes (Sorvari and Korhola, 1998; Smol et al., 2005). The mechanism of that change is probably associated with decreased duration of ice-cover, increased thermal stability, and subsequent changes in internal nutrient dynamics (Sorvari et al., 2002). Peatlands are among the most widespread and productive of the aquatic ecosystems in Lapland, but, when temperatures rise and the growing season extends, there may well be a shift in dominant vegetation from lichens and mosses to vascular plants. The increase in temperature could result in reduced water storage in northern peatlands, even with a small and persistent increase in precipitation (Rouse et al., 1997). In the context of such changes in environmental conditions the present survey provides a solid baseline for the ostracod fauna in 2011 against which any future changes in species composition in Lapland freshwater bodies can be assessed.

\section{ACKNOWLEDGEMENTS}

This study was supported by funds from the University of Gdańsk (project no. BW-1130-5-0004-4). Grateful thanks go to Wojciech Giłka (University of Gdańsk) for enabling the first author to participate in the expedition and for help with fieldwork. Special acknowledgements to Prof. Geoff Boxshall for his help in improvement of the manuscript.

\section{REFERENCES}

Abell R, Thieme ML, Ravenga C, Bryer M, Kottelat M, Bogutskaya N, Coad B, Mandrak N, Contreras Balderas S, Bussing W, Stiassny MLJ, Skelton P, Allen GR, Unmack P, Naseka A, $\mathrm{Ng}$ R, Sindorf N, Robertson J, Armijo E, Higgins JV, Heibel TJ, Wikramanayake E, Olson D, López HL, Reis RE, Lundberg JG, Sabaj Pérez MH, Petry P, 2008. Freshwater ecoregions of the world: A new map of biogeographic units for freshwater biodiversity conservation. Bioscience 58:403-414.

ACIA, 2004. Arctic climate impact assessment. Impacts of a warming arctic: Arctic climate impact assessment. Cambridge University Press, Cambridge, UK.

Agbeti MD, Kingston JC, Smol JP, Watters C, 1997. Comparison of phytoplankton succession in two lakes in different mixing regimes. Arch. Hydrobiol. 140:37-69.

Akatova NA, Järvekülg AA, 1965. Muschelkrebse (Ostracoda) der Seen Kareliens, p. 147-152. In: Fauna ozer Karelii, Bespozvonochnye. [in Russian]. Moskva-Leningrad, Russia.

Alm GC, 1914a. Beiträge zur Kenntnis der nördlichen und arktischen Ostracodenfauna. [Article in German]. Ark. Zool. 9:1-20.

Alm GC, 1914b. Beschreibung einiger neuen Ostracoden aus Schweden. [Article in German]. Zool. Anz. 43:468-475.

Alm GC, 1914c. Ostracoden aus den nordschwedischen Hochgebirgen. [Article in German]. Naturwissenschaftliche Untersuchungen des Sarekgebirges in Schwedisch-Lappland 4:639-664.

Alm GC, 1915. Monographie der schwedischen Süsswasser-Ostracoden nebst systematischen Besprechungen der Tribus Podocopa. [Article in German]. Zool. Bidr. Upps. 4:1-248.

Beaugrand G, Reid PC, Ibañez F, Lindley JA, Edwards M, 2002. Reorganization of North Atlantic Marine Copepod Biodiversity and Climate. Science 296:1692-1694.

Clarke KR, Gorley RN, 2006. PRIMER v6: User manual/tutorial. PRIMER-E, Plymouth, UK.

Clarke KR, Warwick RM, 1998. A taxonomic distinctness index and its statistical properties. J. Appl. Ecol. 35:523-531.

Clarke KR, Warwick RM, 2001. Changes in marine communities, an approach to statistical analysis and interpretation. PRIMER-E, Plymouth, UK.

Ekman S, 1908. Ostracoden aus den nordschwedischen Hochgebirgen. [Article in German]. Naturwissenschaftliche Untersuchungen des Sarekgebirges in Schwedisch-Lappland 4:169-198. 
Ekman S, 1914. Beiträge zur Kenntnis der schwedischen Süsswasser-Ostracoden. Zool. Bidr. Upps. 3:1-36.

Hartmann G, 1992. Zur Kenntnis der rezenten und subfossilen Ostracoden des Liefdefjords (Nordspitzbergen, Svålbard). I. Teil. Mit einer Tabelle subfossil nachgewiesener Foraminiferen. [Article in German]. Mitt. Hamb. Zool. Mus. Inst. 89: $181-225$.

Heino J, Virkkala R, Toivonen H. 2009. Climate change and freshwater biodiversity: detected patterns, future trends and adaptations in northern regions. Biol. Rev. 84:39-54.

Iglikowska A, Namiotko T, 2010. Freshwater Ostracoda (Crustacea) of Inari Lapland in northern Finland. Ann. Limnol. Int. J. Lim 46:199-206.

Iglikowska A, Namiotko T, (2011). The influence of abiotic environmental factors on occurrence and diversity of Ostracoda in selected types of freshwater habitats in subarctic and temperate Europe. Ann. Zool. Fenn. (in press).

Korhola A, Weckström J, Blom T, 2002. Relationships between lake and land-cover features along latitudinal vegetation ecotones in arctic Fennoscandia. Arch. Hydrobiol. Suppl. 139:203-205.

Luoto M, Seppälä M, 2000. Summit peats ('peat cakes') on the fells of Finnish Lapland: continental fragments of blanket mires? Holocene 10:229-241.

Martyn D, 1995. Klimaty Kuli Ziemskiej. Wydawnictwo Naukowe PWN, Warszawa, Poland.

Meisch C, 2000. Freshwater Ostracoda of Western and Central Europe. In: J. Schwörbel and P. Zwick (eds.) Süsswasser Fauna von Mitteleuropa, Band 8. Spektrum Akademischer Verlag, Heidelberg-Berlin, Germany: 522 pp.

Paiunen H, 2005. Mires, p. 77-96. In: M. Seppälä (ed.) The physical geography of Fennoscandia. Oxford University Press, New York, USA.

Pulkkinen E, Rissanen K, 1997. A geochemical investigation on overbank sediments in the Inari area, northern Finnish Lapland. J. Geochem. Explor. 59:11-26.

Rouse WR, Douglas MSV, Hecky RE, Hershey AE, Kling GW, Lesack L, Marsh P, McDonald M, Nicholson BJ, Roulet NT, Smol JP. 1997. Effects of climate change on the freshwaters of Arctic and subarctic North America. Hydrol. Process. 11:873-902.

Sars GO, 1890. Oversigt af Norges Crustaceer med forelobige bemaerkninger over de nye eller mindre bekjendte arter: 2 (Branchiopoda, Ostracoda, Cirripedia). [Article in Norwegian]. Forhandlinger I Christiania Videnskabs-Selskabet 1:180.

Sars GO, 1923. Ostracoda. In: An account of the Crustacea of Norway with short descriptions and figures of all the species. Bergen Museum Publ., Bergen, Norway, 3-4:33-72.

Sars GO, 1925. Ostracoda. In: An account of the Crustacea of Norway with short descriptions and figures of all the species. Bergen Museum Publ., Bergen, Norway, 5-10:73-208.

Selin P, Hakkari L, 1982. The diversity, biomass and production of zooplankton in Lake Inarijärvi. Hydrobiologia 86:55-59.

Semenova LM, 2003. Distribution and zoogeography of ostracods (Crustacea, Ostracoda) in waterbodies of the Novaya Zemlya
Archipelago and Island Vaigach. [Article in Russian]. Inland Water Biol. 2:20-26.

Silfverberg H, 1999. A provisional list of Finnish Crustacea. Memoranda Soc. Fauna Flora Fennica 75:15-37.

Smol JP, Wolfe AP, Birksf HB, Douglas MSV, Jones VJ, Korhola A, Pienitz R, Rühland K, Sorvari S, Antoniades D, Brooks SJ, Fallu MA, Hughes M, Keatley BE, Laing TE, Michelutti N, Nazarova L, Nyman M, Paterson AM, Perren B, Quinlan R, Rautio M, Saulnier-Talbot E, Siitonen S, Solovieva N, Weckström J, 2005. Climate-driven regime shifts in the biological communities of arctic lakes. P. Natl. Acad. Sci. USA 102:4397-4402.

Sorvari S, Korhola A, 1998. Recent diatom assemblage changes in subarctic Lake Saanajärvi, NW Finnish Lapland, and their paleoenvironmental implications. J. Paleolimnol. 20:205-215.

Sorvari S, Korhola A, Thompson R, 2002. Lake diatom response to recent Arctic warming in Finnish Lapland. Global Change Biol. 8:153-163.

Stebel K, Christensen GN, Derome J, Grekelä I, 2007. State of the environment in Norwegian, Finnish and Russian border area. Finn. Environ. 6:1-68.

Sywula T, 1974. Małżoraczki (Ostracoda). In: Fauna Słodkowodna Polski 24. Wydawnictwo Naukowe PWN, Warszawa/Poznań, Poland: 315 pp.

Sywula T, Namiotko T, Sell J, Witkowski A, Zajączkowski M, 1994. Crustacean species new to Spitsbergen with notes on the polymorphism and the subfossil preservation of Cytherissa lacustris (G.O. Sars). Polar Res. 13:233-235.

Szeroczyńska K, Tatur A, Weckström J, Gąsiorowski M, Noryśkiewicz AM, Sienkiewicz E, 2006. Holocene environmental history in northwest Finnish Lapland reflected in the multi-proxy record of a small subarctic Lake. J. Paleolimnol. 38:25-47.

Tikkanen M, 2005. Climate, p. 97-112. In: M. Seppälä (ed.) The physical geography of Fennoscandia. Oxford University Press, Oxford, UK.

Tolonen A, 1997. Size-specific food partitioning and growth in benthic whitefish, Coregonus lavaretus (L.), in a subarctic lake. Boreal Environ. Res. 2:387-399.

Väisänen R, Heliövaara K, Immonen A, 1992. Biogeography of northern European insects: province records in multivariate analysis (Saltatoria, Lepidoptera, Sesiidae, Coleoptera, Buprestidae, Cerambycidae). Ann. Zool. Fenn. 28:57-81.

Vekhov NV, 2000a. Crustaceans from small waterbodies on islands of the eastern Barents Sea and the Karskije Vorota strait. Inland Water Biol. 2:42-48.

Vekhov NV, 2000b. Crustaceans from waterbodies of polar deserts on the Novaya Zemlya archipelago (Euro-Arctic region of the Barents Sea). Inland Water Biol. 3:16-23.

Vekhov NV, 2001. Crustaceans from rockpools of islands and the shore of the Kandalaksha Bay of the White Sea. [Article in Russian]. Inland Water Biol. 3:20-28.

Wilson EO, 2005. Systematics and the future of biology. P. Natl. Acad. Sci. USA 102:6520-6521.

Wojtasik B, 2008. Life cycle of Tonnacypris glacialis (Crustacea: Ostracoda). Polish Polar. Res. 29:33-44. 